\title{
Öğretmen Adaylarının Lisansüstü Eğitime İlişkin Metaforik Algiları
}

\section{Metaphorical Perceptions of Prospective Teachers toward Graduate Education}

\author{
Ebru Bozpolat, Yrd. Doç. Dr., Cumhuriyet Üniversitesi Eğitim Fakültesi, ebozpolat@gmail.com
}

\begin{abstract}
öZ: Bu araştırmanın amacı; öğretmen adaylarının lisansüstü eğitime ilişkin metaforik algılarını ortaya koymaktır. Nitel bir yapıda olan araştırmada, olgu bilim (fenemonoloji) deseni kullanılmıştır. Araştırmanın çalışma grubu; 2014-2015 eğitim-öğretim yılı bahar döneminde Cumhuriyet Üniversitesi Eğitim Fakültesi Okul Öncesi Öğretmenliği, Sınıf Öğretmenliği, İlköğretim Matematik Öğretmenliği, Sosyal Bilgiler Öğretmenliği, Fen Bilgisi Öğretmenliği, Rehberlik ve Psikolojik Danışmanlık ve Türkçe Öğretmenliği dördüncü sınıfta öğrenim gören 112 öğretmen adayından oluşmaktadır. Araştırma verileri, "Lisansüstü eğitim ............a/e benzer; çünkü .............." șeklinde eksik bırakılmış bir cümleden oluşan form aracıllğıyla toplanmıștır. Verilerin analizinde, nitel araştırma desenine uygun olarak içerik analizi yöntemi kullanılmıştır. Araştırma sonucunda; 112 öğretmen adayl 93 farklı metafor geliştirmiş ve bu metaforlar "Gelişim", "Zirve", "Değer", "Zor", "Çaba", "Uzmanlık", Keşif-Araștırma", "Yol Gösterici", Doyumsuzluk" ve "Üretim" olmak üzere 10 kategoride toplanmıştır.

Anahtar kelimeler. Lisansüstü eğitim, Metafor, Öğretmen adayı
\end{abstract}

\begin{abstract}
The aim of this study is to investigate metaphorical images of prospective teachers toward the concept of graduate education. The research has been conducted in line with the phenomenology pattern. The study group of the research consists of 112 senior prospective teachers who were studying in the Cumhuriyet University, Faculty of Education in the spring semester of the 2014-2015 academic years. Data of the study were collected through the use of the prompt "Graduate Education looks like .............. because .............". Content analysis method was used to analyze the data. When research results are examined; 112 prospective teachers developed 93 different metaphors for graduate education. These metaphors are categorized into 10 conceptual categories with regard to their common features.
\end{abstract}

Keywords. Graduate education, Metaphor, Prospective teacher

\section{SUMMARY}

Purpose and significance: The aim of this study is to investigate metaphorical images of prospective teachers toward the concept of graduate education. In line with this aim, the research problem has been determined as "What is the metaphoric perception of prospective teachers toward the concept of graduate education under which cognitive categories are these included when we take the metaphoric properties they have into the consideration?

Methods: The research has been conducted in line with the phenomenology pattern. The study group of the research consists of senior prospective teachers who were studying in the Cumhuriyet University, Faculty of Education in the spring semester of the 2014-2015 academic years.112 prospective teachers participated in the research and participation was on a volunteer basis. A questionnaire which was prepared by the researcher was used to collect the research data. In the first part of the questionnaire, the personal information of the prospective teachers was included; in the second part questionnaire, sentences such as "Graduate Education looks like because ............." were used to learn the opinions of the prospective teachers about graduate education. The content analysis method consistent with the qualitative research pattern was used in the evaluation of the obtained data. The questionnaires that prospective teachers filled were examined carefully and studiously. First of all, the metaphors that prospective teachers created were listed and then listed metaphors were classified. Then, categories were determined by taking the justifications of the metaphors into consideration.

Results: When research results are examined; 112 prospective teachers developed 93 different metaphors for graduate education. These metaphors are categorized into 10 conceptual categories with regard to their common features. These categories was determined as 
"Development" (f: 26), "Summit" (f: 23), "Value" (f: 17), "Difficult" (f: 12), "Effort" (f: 8), "Specialization" (f: 6), "Reconnaissance-explorative" (f: 6), "Guiding" (f: 5), "Insatiable" and "Production" (f: 4).

Discussion and Conclusions: When the findings were evaluated in general by examining the metaphorical images of prospective teachers, it can be said that prospective teachers had a positive attitude towards graduate education. It is seen that it is the categories with the highest frequency of the "Development" and "Summit" categories in the research which was followed by the "Value", "Effort", "Difficult", "Specialization", "Reconnaissance-explorative", "Guiding", "Insatiable" and "Production" categories. Accordingly, by allowing to participate of prospective teachers in the graduate programs, it should contribute both to occur a strong and well qualified academic environment and to the training of more qualified teachers.

\section{Giriş}

Bilgi çağının yaşandığı, bilim ve teknolojinin hızla gelişimine devam ettiği günümüzde araștıran, sorgulayan, eleştirel ve yaratıcı düşünen, bilgiyi üreten, analiz ve sentez gibi üst düzey düşünme becerilerini kullanabilen bireylere duyulan ihtiyaç her geçen gün artmaktadır. Hızlı gelişme ve değişmeler sonucu, mevcut bilgiler kısa sürede geçerliliğini ve işlevini yitirmektedir. Bundan dolayı küreselleşen dünyada bireyin kendisini sürekli geliştirmesi ve eğitim sürecinin içerisinde daha fazla yer almasını zorunlu hale gelmektedir (Tavukçu, Özkardaş, Erzurum, Çiftçi, Şahin ve Bilgin, 2013). Bu durum ise eğitimin önemini bir kat daha artırmakta ve eğitim kurumlarının işlevlerinin gözden geçirilmesini zorunlu kılmaktadır.

Sürekli gelişen ve değişen dünyada, eğitim kurumlarının toplumsal ihtiyaç ve beklentiler doğrultusunda yapılandırılması ve devamlı yenilenmesi gerekmektedir (Ünal ve İlter, 2010). Eğitim kurumlarının öğrenci, öğretmen ve program olmak üzere birbiriyle etkileşimli üç öğesi bulunmaktadır. Eğitim kurumlarındaki nitelik ve kalite arayışı eğitim sisteminin en önemli öğesi olan öğretmenlerin niteliğiyle doğru orantılıdır (Şişman, 2006). Herhangi bir ülkede, öğretmenler ve öğretmenlik mesleği yeterli güç ve niteliğe ulaşmadıkça, o ülkede en iyi eğitim sistemi ve en yüce eğitim amaçları da bulunsa, gelişim gerçekleşemez (Akyüz, 2010). Öğretmenlerin doğru yetiştirilerek, niteliklerinin artırılması onların hem mesleki hem de akademik yaşamlarındaki başarılarını beraberinde getirecektir. Eğitim kurumlarında daha iyi eğitilen öğretmenlerin daha verimli çalışacakları ve gelecek kuşakları daha iyi yetiştirecekleri varsayımı lisansüstü eğitime olan ilgiyi bir kat daha artırmaktadır. Yükseköğretim Kurumu'nun da (1982-2007) belirttiği gibi, öğretmenlik mesleği kendine özgü ilke ve uygulama yöntemleriyle profesyonel statüde bir meslektir. Bundan dolayı, öğretmen eğitiminin, öncelikle nitelikli ve sağlıklı bir lisans eğitimine dayandırılması ve daha sonrasında öğretmenlerin lisansüstü eğitim olanaklarından yararlanmasına imkân sağlanmalıdır.

Yükseköğretim Kurulu Lisansüstü Eğitim ve Öğretim Yönetmeliği'ne göre lisansüstü eğitim yüksek lisans ve doktora eğitim ile sanat dallarında yapılan sanatta yeterlik çalışması ve tıpta uzmanlık ile bunların gerektirdiği eğitim öğretim bilimsel araştırma ve uygulama etkinliklerinden oluşan eğitim olarak tanımlanmaktadır (Madde 1, 2 ve 3). Yönetmelikte lisansüstü eğitim programlarının amaçları; tezli yüksek lisans programı için "öğrencinin bilimsel araştırma yaparak bilgilere erişme, bilgiyi değerlendirme ve yorumlama yeteneğini kazanmasını sağlamak" (Madde 9), tezsiz yüksek lisans programı için" öğrenciye mesleki konuda derin bilgi kazandırmak ve mevcut bilginin uygulamada nasıl kullanılacağını göstermek" (Madde 14), doktora programı için ise "öğrenciye bağımsız araştırma yapma bilimsel olayları geniş ve derin bir bakış açısı ile irdeleyerek yorum yapma ve yeni sentezlere ulaşmak için gerekli adımları belirleme yeteneği kazandırmak" (Madde 18) olarak belirtilmiştir (Yükseköğretim Kurulu Lisansüstü Eğitim ve Öğretim Yönetmeliği, 2015)

Lisansüstü eğitim, üniversitede lisansüstü derecelere götüren, araştırma yoluyla bilgiye katkıda bulunacak ve gelişen toplumun ihtiyaçlarını karşılayacak bilim insanı ve öğretim elemanı yetiştirmeyi amaç edinen bir faaliyettir (Varıs, 1972; Bülbül 2003). Başka bir ifade ile lisansüstü eğitim, herhangi bir bilgi alanında derinlemesine çalışarak uzmanlaşılan, lisans eğitiminden daha 
üst seviyede bilgi ve etkinliğe sahip olan, yüksek ihtisas gücünü yetiştiren eğitim programıdır (Köksalan, İlter ve Görmez, 2010; Çakar, 2001). Benzer bir ifade ile Sevinç (2001), lisansüstü eğitimin ülke kalkınmasında ve ülkenin gereksinim duyduğu yüksek nitelikli insan tipinin oluşmasında önemli bir rolü olduğunu belirtmektedir. Aslan (2010) ise lisansüstü eğitimi yaratıcl, araştırmacı, etik değerlere saygıll, sorunlara akılcı yöntemlerle çözüm üretebilen, bilimsel bakış açısı kazanmış, grup çalışması ve disiplinler arası çalışmalara katılmaya istekli, nitelikli çalışmalar üretebilen ve bu yolla toplumun ihtiyaçlarına yanıt veren bilim insanları yetiştirmek olarak ifade etmiştir. Günümüzde lisansüstü öğretimin örgün öğretimin bir düzeyi durumuna gelen belli programlar uygulayan, belli dereceler veren planlı bir etkinlik olduğu söylenebilir (Karakütük, 2001). Bu doğrultuda; üniversitelerin işlevleri ile lisansüstü eğitimin işlevlerinin birbiri ile benzerlik gösterdiğini ifade eden Arıcı (2001) lisansüstü eğitimin işlevlerini bilim üretmek ve yaymak, toplumsal sorunları doğru algılama ve sorunlara çözüm önerileri geliştirme ve üst düzey insan gücünün yetiştirilmesi olarak ortaya koymaktadır. Bu çerçevede sorunlara akılcı çözümler üretebilen, grup çalışmalarına katılan, içinde yaşadığı topluma uyum sağlayabilen ve nitelikli çalışmalar üreterek toplumun gereksinimlerine yanıt veren bilim insanları yetiştirmenin lisansüstü öğretimin öncelikli hedefleri arasında olduğu (Gömleksiz ve Yıldırım, 2013) söylenebilir.

Özellikle öğretmenlerin, akademik yükselmenin yanı sıra lisans sonrasında da iș bașında eğitimini sürdürmelerinde uzmanlaşma, kendi niteliğini yükseltme, eğitim alanındaki yenilikleri takip etme ve sınıf ortamında bunları uygulayabilmeleri (Alabaş, 2011) bakımından da lisansüstü eğitimin önemine vurgu yapılmaktadır. Milli Eğitim Bakanlığı'nın, 2010-2014 Stratejik Planında, politika ve strateji olarak iyi eğitilmiş ve yüksek düzeyde motive edilmiş öğretmenlerin kaliteli eğitimin en önemli unsuru olduğu belirtilmekte, bu bağlamda öğretmen eğitiminin geliștirilmesi yanında, öğretmenlerin kendi alanlardaki kariyer gelişimlerinin de destekleneceği belirtilmektedir. Ayrıca açık öğretim programı uygulayan üniversiteler ile iș birliği yapılarak tüm personelin alanlarında yüksek lisans derecesi alması teşvik edileceği (Milli Eğitim Bakanlığı, 2009) ifadesi de öğretmenlerin lisansüstü eğitime yönelmeleri fikrini desteklemektedir. Milli Eğitim Şuraları'nda da öğretmenlerin lisansüstü eğitime yönlendirilmeleri konusunda kararlara rastlanmaktadır. 15. Milli Eğitim Şurası'nda yer alan "Öğretmenler yüksek lisans ve doktoraya yönlendirilmeli; hizmet içi eğitimi düzenleyip örgütleyebilmesi ve öğretmenlikle ilgili araştırma ve geliştirmeleri destekleyebilmesi için Millî Eğitim Akademisi hayata geçirilmelidir" (MEB, 1996) ifadesi ile 18. Milli Eğitim Şurası'nda yer alan "Okul yöneticilerinin atamasında, lisansüstü eğitim görme esas alınmalı, mevcut yönetici ve öğretmenlerin kişisel gelişimleri açısından üniversiteler ile Millî Eğitim Bakanlığı arasında gerekli koordinasyonla uzaktan veya örgün eğitim yoluyla yüksek lisans ve doktora eğitimi almaları sağlanmalı, bu bağlamda verilecek izinler yasal bir düzenlemeyle güvence altına alınmalı, bu öğretmenlerin maaşlarında belirli oranda artış sağlanmal, yüksek lisans derecesine sahip olanlara uzman öğretmenlik, doktora derecesine sahip olanlara başöğretmenlik unvanı verilmelidir." (MEB, 2010) ifadesi öğretmenlerin lisansüstü eğitime yönlendirilmesi düşüncesini desteklemektedir.

Verilen bilgiler ışığında; lisansüstü eğitimin, gelecek nesillerin eğitimlerinde görev alacak olan öğretmen adaylarının kişisel ve mesleki gelişiminde etkili olduğunu söylemek mümkündür. Bu doğrultuda, öğretmen adaylarının lisansüstü eğitime ilişkin bakış açılarının ortaya konması önemli görülmüștür. Öğretmen adaylarının görüşlerinin belirlenmesinde; bireylerin açıklayamadıkları kavramları ya da durumları açıklamalarında günlük hayatlarında kullandıkları bazı benzetme unsurlarını kullanmalarına imkân sağlayan metafor yönteminin kullanılmasına karar verilmiştir. Cerit (2008) metaforların bireylerin çevreyi ve hayatı açıklamaya çalıştıkları araçlar olduğunu vurgulamaktadır. Kavramlardan biri iyi biliniyorsa diğerini anlatmak daha kolay olacaktır (Tamimi, 2005). Böylece bireylerin kavramları açılamalarında benzetmeler aracılı̆̆ıyla zihinlerindeki durumları daha kolay ortaya çıkarmaktadır.

Metafor çalışmaları ile bilinen Lakoff ve Johnson (2005)'e göre metafor “bir şeyi başka bir şeyin bakış açısıyla anlamak ve tecrübe etmek, bir düşünce malzemesini, insan kavrayışının bir şekli ile ifade etme sürecidir. Metafor sadece bir söz figürü değil aynı zamanda bir düşünce figürüdür". Metafor, bir konuyu diğer bir konunun bakış açısından algılamaya ve anlamaya izin veren zihindeki bilgiler arasında bir bağ kurma sürecidir (Eraslan, 2011). Böylece metaforların 
bireylerin düşünce ve eylemlerine yön veren yapılar olduğu söylenebilir. Metaforlar, "eğitimcilere iki şey arasında karşılaştırma yapmak, iki şey arasındaki benzerliklere dikkat çekmek veya bir şeyi başka bir şeyin yerine koyarak açılamak için firsat tanırlar" (Saban, 2004). Öğretmen adaylarının lisansüstü eğitime yönelik algılarının lisansüstü eğitime yönelmelerinde ve lisansüstü eğitiminin gereklerini yerine getirebilmelerinde etkili olabileceği bir gerçektir. Bu çerçevede öğretmen adaylarının, lisansüstü eğitime ilişkin algılarının metaforlar aracılığıyla belirlenmesinin alana katkı sağlayacağı düşünülmektedir. Böylece öğretmen adaylarının lisansüstü eğitime ilişkin algılarını hangi metaforlarla ortaya koydukları, ortaya çıkan metaforların gerekçeleri ve bu metaforların ortak özellikleri belirlenmeye çalışılmıştır.

\section{Araştırmanın amacı}

$\mathrm{Bu}$ araştırmanın amacl; öğretmen adaylarının lisansüstü eğitime ilişkin metaforik algılarını ortaya koymaktır. Bu amaç doğrultusunda; öğretmen adaylarının lisansüstü eğitime ilişkin sahip oldukları metaforik algıların neler olduğu ve sahip oldukları metaforik özellikler dikkate alındığında hangi kavramsal kategoriler altında yer aldığı belirlenmiștir.

\section{YÖNTEM}

\section{Araştırma deseni}

Nitel bir yapıda olan bu araştırmada, olgu bilim (fenemonoloji) deseni kullanılmıştır. Bilinen; ancak aynı zamanda tam anlamıyla kavranamayan olguları araştırmayı amaçlayan olgu bilim deseni; algıların, yönelimlerin ve kavramların araştırılmasında uygun bir desendir (Yıldırım ve Şimşek, 2006). Olgu bilim, bireylerin olgu ve olaylara ilişkin tecrübelerini nasıl anlamlandırdıklarını ve bu anlamları başkalarıyla nasıl paylaştıklarını anlamaya çalışması (Merriam, 2013; Patton, 2002) açısından önemli görülmektedir.

\section{Çalıșma grubu}

Araştırmanın çalışma grubu; 2014-2015 eğitim-öğretim yılı bahar döneminde Cumhuriyet Üniversitesi Eğitim Fakültesi Okul Öncesi Öğretmenliği (OÖÖ), Sınıf Öğretmenliği (SÖ), İlköğretim Matematik Öğretmenliği (İMÖ), Sosyal Bilgiler Öğretmenliği (SBÖ), Fen Bilgisi Öğretmenliği (FBÖ), Rehberlik ve Psikolojik Danışmanlık (PDR) ve Türkçe Öğretmenliği (TÖ) dördüncü sınıfta öğrenim gören öğretmen adaylarından oluşturmaktadır. Katılımın gönüllülük esasına dayandığı araştırmaya toplam 121 öğretmen adayı katılmıștır. Yapılan inceleme sonucunda eksik ve amacına uygun doldurulmadığı belirlenen 9 araştırma formu değerlendirme dıșı bırakılmış ve toplam 112 form geçerli sayılarak analiz gerçekleştirilmiştir.

Araştırmaya kapsamına alınan 112 katılımcının 78'i kız, 34'ü erkek öğretmen adaylarından oluşmaktadır. Öğretmen adaylarının 22'si Türkçe Öğretmenliği, 21'i Okul Öncesi Öğretmenliği, 19'u Sinıf Öğretmenliği, 13'ü Sosyal Bilgiler Öğretmenliğgi, 13'ü İlköğretim Matematik Öğretmenliği, 12'si Rehberlik ve Psikolojik Danışmanlık ve 12'si Fen Bilgisi Öğretmenliği dördüncü sınıfta öğrenim görmektedir. Araştırma grubunun seçimi, seçkisiz olmayan örnekleme yöntemlerinden amaçlı örnekleme yöntemlerinden kolay ulaşılabilir durum örneklemesine uygun olarak yapılmıştır (Yıldırım ve Şimşek, 2006).

\section{Veri toplama aracı ve verilerin toplanması}

Araştırma verilerinin toplanmasında, araştırmacı tarafından hazırlanan ve iki bölümden oluşan form kullanılmıștır. Formun birinci bölümünde; öğretmen adaylarına ilișkin cinsiyet ve öğrenim gördükleri bölümleri belirtebilecekleri kişisel bilgiler bölümüne yer verilmiştir. Formun ikinci bölümünde ise öğretmen adaylarının lisansüstü eğitime ilişkin algılarını belirlemek amacıyla "Lisansüstü eğitim a/e benzer; çünkü .", şeklinde eksik bırakılmış bir cümle yer almaktadır. Bu cümle aracılığıyla "benzer" kelimesiyle öğretmen adaylarının lisansüstü eğitime ilişkin algılarının hangi metaforla çağrışım yaptığı belirlenirken; "çünkü" ile başlayan kısımda ise ortaya çıkan metaforların gerekçeleri ortaya konmaya çalışılmıştır. Formların doldurulması sırasında öğretmen adaylarına yeterli süre tanınmıștır. 


\section{Verilerin analizi}

Elde edilen verilerin değerlendirilmesinde, nitel araştırma desenine uygun olarak içerik analizi yöntemi kullanılmıștır. İçerik analizinde temel amaç, toplanan verilerin açıklanabileceği kavramlara ve ilişkilere ulaşmaktır. Bu süreçte; veriler, derin bir işleme tabi tutularak üzerinde çalışılan konuya ilişkin kavram ve temaların keşfedilmesi sağlanır. Birbirine benzeyen veriler mantıklı bir biçimde bir araya getirilir ve anlaşılır şekilde düzenlenerek yorumlanır (Yıldırım ve Şimşek, 2006).

Öğretmen adaylarının doldurdukları formlar dikkatli bir şekilde ve titizlikle incelenmiştir. Metaforlar tek tek kodlanmış ve amaca uygun doldurulmayan, eksik ya da boş bırakılan 9 form ayıklanarak araştırma kapsamı dışında bırakılmıştır. Böylece, toplam 112 adet geçerli metafor elde edilmiştir. Öncelikle katılımcılar tarafından üretilen bu metaforlar alfabetik sıraya göre dizilmiş ve geçici bir liste oluşturulmuştur. Bunu yapmaktaki amaç katılımcıların belli bir metaforu net bir şekilde dile getirip getirmediğini ortaya koymaktır. Daha sonra listelenen metaforlar gruplandırılmış ve son olarak metaforların gerekçeleri de dikkate alınarak kategoriler belirlenmiștir.

Nitel araştırmalara en önemli eleştirilerden biri, geçerlik ve güvenirlik sorunudur. Öncelikle, nitel araştırmalarda geçerliği yani inandırıcılığı sağlamak önemlidir. Araştırmacının, toplanan verileri ayrıntılı olarak rapor etmesi ve sonuçlara nasıl ulaştığını açıklaması nitel bir araştırmada geçerliğin sağlanmasında önemli ölçütlerden biridir (Yıldırım ve Şimşek, 2005). Bu nedenle, mevcut araştırmada özellikle bulgular kısmında, metaforlara ilişkin kategorilere nasıl ulaşıldığı ve metaforların gerekçeleri ayrıntılı bir şekilde belirtilmiştir.

Araştırmanın güvenirliğini sağlamak amacıyla, araștırmada ulaşılan kavramsal kategori altında verilen metaforların söz konusu kavramsal kategoriyi temsil edip etmediğini teyit etmek amacıyla uzman görüşüne (Ölçme ve Değerlendirme Anabilim dalından bir Yrd. Doç. Dr.) sunulmuştur. Daha sonra, uzman ile araştırmacı tarafından yapılan eşleştirmeler karşılaştırılmıştır. Araştırmanın güvenirliği Miles ve Huberman'ın (1994) formülü ile hesaplanmıştır.

Miles ve Huberman'ın Güvenirlik Formülü = Görüş birliği / Görüş birliği + Görüş ayrılı̆ğ

$$
\begin{aligned}
& =109 / 109+3 \\
& =0,97
\end{aligned}
$$

Formülden elde edilen sonuç doğrultusunda; uzman ve araştırmacı değerlendirmeleri arasında \% 97 oranında bir uzlaşma (güvenirlik) sağlandığı görülmektedir. Miles ve Huberman (1994) güvenirlik sonucunun \% 70'in üzerinde çıkmasının araştırmanın güvenirliği için geçerli bir oran olduğunu; Saban (2008) ise nitel çalışmalarda, uzman ve araştırmacı değerlendirmeleri arasındaki uyumun \% 90 ve üzeri olması istenilen güvenirliğin sağlandığının göstergesi olduğunu ifade etmektedir.

Elde edilen verilerinin hangi öğretmen adayına ait olduğu (kodlandığı numara, bölüm ve cinsiyeti aracılığılla) belirtilerek metaforların çözümlemesi yapılmıştır. Yapılan çözümlemeler sonucu oluşan kategoriler belirlenmiş ve çözümlemelere kaynaklık eden öğretmen adaylarının doğrudan alıntılarına metin içerinde yer verilmiştir. Alıntılar, üzerinde hiçbir değiş̧iklik yapılmadan tırnak içerisinde italik yazı stiliyle bulgular ve yorum bölümünde yer almıştır. Aynı zamanda kimlik gizliliği göz önünde bulundurularak alıntıların alındığı yeri belirten açılayıcı kısaltmalar yapılmıştır. Örneğin; elde edilen doğrudan alıntıların başına, "ÖA1-SÖ-K" biçiminde açıklayıcı bir ifade yazılmıştır. Bu ifade içerisinde yer alan kısaltmaların açılımı aşağıda belirtilmiştir:

$$
\begin{aligned}
& \text { “ÖA1" = Öğretmen adayl-1 (Kaynak kişi ve sırası) } \\
& \text { "SÖ" = Sinıf Öğretmenliği (Bölümü) } \\
& \text { "K" }=\mathrm{Kiz} \quad \text { (Cinsiyeti) }
\end{aligned}
$$




\section{BULGULAR VE YORUM}

Bu bölümde, öğretmen adaylarının lisansüstü eğitim kavramına ilişkin oluşturdukları metaforlar ve bu metaforlardan oluşan kategoriler tablolaştırılmış ve yorumlanmıștır. Lisansüstü eğitim kavramına ilişkin 112 öğretmen adayı 93 farklı metafor geliştirmiş ve bu metaforlar “Gelişim" (f: 26), "Zirve” (f: 23), "Değer" (f: 17), "Zor" (f: 12), “Çaba" (f: 8), “Uzmanlık” (f: 6), KeşifAraștırma" (f: 6), "Yol Gösterici" (f: 5), Doyumsuzluk" (f: 5) ve "Üretim" (f: 4) olmak üzere 10 kategoride toplanmıştır. Ayrıca her bir kategoriye ilişkin başlık altında ilgili kategorilerin oluşmasını kaynaklık eden öğretmen adaylarının ifadelerinden örneklere de yer verilmiştir.

\section{Gelişim Kategorisine İliş̧kin Bulgular}

Öğretmen adaylarının lisansüstü eğitim kavramına ilişkin oluşturdukları ve "Gelişim" kategorisi altında yer alan metaforlar Tablo 1'de yer almaktadır.

Tablo 1. Öğretmen adaylarının gelişim kategorisine iliş̧in metaforları

\begin{tabular}{|c|c|c|c|c|c|}
\hline KATEGORÍ & $\sum f$ & METAFOR & $f$ & KAYNAK KIŞİ & BENZETME YÖNÜ \\
\hline \multirow{25}{*}{ GELİŞIM } & \multirow{25}{*}{26} & $\begin{array}{l}\text { Tereyağlı ekmeğin üstündeki } \\
\text { bal }\end{array}$ & 2 & $\begin{array}{l}\text { ÖA72-SBÖ-K } \\
\text { ÖA41-OÖÖ-K }\end{array}$ & Bilgi birikimi sağlama \\
\hline & & Merdiven & 1 & ÖA69-SBÖ-K & Her adımda öğrenme \\
\hline & & Yeni sürüm teknolojik alet & 1 & ÖA71-SBÖ-E & Sürekli yenilenme \\
\hline & & Çorba malzemelerinden biri & $\mathbf{1}$ & ÖA81-İMÖ-K & Gelişmeye katkı sağlama \\
\hline & & Yeni yapılan bina & $\mathbf{1}$ & ÖA87-İMÖ-K & Bilgi ekleme \\
\hline & & Dalda kalan son elma & 1 & ÖA92-FBÖ-K & Olgunlașma \\
\hline & & Aile & 1 & ÖA95-FBÖ-E & Gerekli donanıma sahip olma \\
\hline & & İnsanın yașlanması & 1 & ÖA96-FBÖ-E & Tecrübe sahibi olma \\
\hline & & Yeni model saat & 1 & ÖA97-FBÖ-E & Daha donanımlı olma \\
\hline & & Ağaca așı yapma & 1 & ÖA44-SÖ-K & Gelișimin artırma \\
\hline & & Yazarlık yapma & 1 & ÖA47-SÖ-K & Kendini geliştirme \\
\hline & & Yarıșma & 1 & ÖA54-SÖ-K & Bilgi birikimi \\
\hline & & Kirazın olgunlașması & 1 & ÖA58-SÖ-K & Olgunlașma \\
\hline & & Sağlam binaya kat çıkma & 1 & ÖA62-SÖ-K & Bilgi birikimi \\
\hline & & Kütüphane & $\mathbf{1}$ & ÖA27-0ÖÖ-K & Bilgi birikimine sahip olma \\
\hline & & Çok kitap okuma & 1 & ÖA29-0ÖÖ-K & Çok bilgiye sahip olma \\
\hline & & Papağan & 1 & ÖA32-0ÖÖ-K & Kendini geliștirme \\
\hline & & Fidanın ağaç olması & 1 & ÖA39-0ÖÖ-K & Așama așama gelișmesi \\
\hline & & Meyve & 1 & ÖA12-TÖ-E & Olgunlaşma \\
\hline & & Ekonomik büyüme & 1 & ÖA17-TÖ-E & Sürekli gelișme, büyüme \\
\hline & & Ağacın dalları & 1 & ÖA21-TÖ-E & Ayrı ayrı büyüme \\
\hline & & Değerli taşları işleme & 1 & ÖA103-PDR-K & Kendi alanında gelişme \\
\hline & & Pokemon & 1 & ÖA104-PDR-E & Sürekli gelișme \\
\hline & & Kitap & 1 & ÖA105-PDR-K & Bilgi birikimi artırma \\
\hline & & Așçı & 1 & ÖA106-PDR-K & Gelişmeye katkı sağlama \\
\hline
\end{tabular}

En çok yükleme yapılan kategori “Gelişim” kategorisidir. Tablo 1'de görüldüğü gibi, "Gelişim" kategorisinin oluşmasını kaynaklık eden 26 öğretmen adayı 25 farklı metafor geliştirmiştir. Bu metaforlar; tereyağlı ekmeğin üstündeki bal, merdiven, yeni sürüm teknolojik alet, çorba malzemelerinden biri, yeni yapılan bina, dalda kalan son elma, aile, insanın yașlanması, yeni model saat, ağaca aşı yapma, yazarlık yapma, yarışma, kirazın olgunlaşması, sağlam binaya kat çıkma, kütüphane, çok kitap okuma, papağan, fidanın ağaç olması, meyve, ekonomik büyüme, ağacın dalları, değerli taşları işleme, pokemon, kitap ve aşçı metaforlarıdır. Bu kategoriye kaynaklık eden öğretmen adaylarının verdikleri cevaplardan örnek ifadelere aşağıda yer verilmiștir. Lisansüstü eğitimi; her adımda öğrenme olarak gören bir öğretmen adayı (ÖA69-SBÖ-K) "Lisansüstü eğitim merdivene benzer; çünkü merdivenin kullanım amacı ulaşamadı̆̆ımız bir yere uzanmak için tırmanmaktır. Her adımda bir şey öğrenirsin, kendini alanında geliştirmiş olursun ve bu sayede bir şey başarmış olursun, kişinin kendisine güveni artmış olur." diyerek, bilgi birikimi sağlamak olarak gören bir öğretmen adayı (ÖA62-SÖ-K) "Lisansüstü eğitim sağlam bir binaya kat çıkmaya 
benzer; çünkü bugüne kadar öğrendiği bilgilerinin üzerine ekleme yaparak yoluna devam eder." diyerek gelişim kategorisinin oluşmasına kaynaklık etmiştir. Bir başka öğretmen adayının (ÖA270ÖÖ-K) "Lisansüstü eğitim kütüphaneye benzer; çünkü kütüphane insanların bilgiye ulaşabildikleri yerlerdir. Zamanla yeni oluşmuş bilgilerin de oradaki kaynaklar içerisinde olması gerekmektedir. Bu yüzden kütüphaneler büyür. Farkll, yeni kaynaklar da barındırır ve bilgiye ulașımı kolaylaştırır. Lisansüstü eğitim de bu kütüphaneye benzer. Belli bilgi birikimine sahip öğrencilerin bilgilerine bilgi katıp o bilgilerini üniversite öğrencileriyle paylaşması değil midir?" șeklindeki ifadesi de gelişme kategorisi içerisinde yer alan görüsslerdendir. Lisansüstü eğitimi donanımlı olmak olarak gören bir öğretmen adayı ise (ÖA97-FBÖ-E) "Lisansüstü eğitim yeni model saate benzer; çünkü eski model saatlere göre daha fonksiyonludur." sözleri ile gelişim kategorisi içerisinde yer almıştır.

\section{Zirve Kategorisine İlişkin Bulgular}

Öğretmen adaylarının lisansüstü eğitim kavramına ilişkin oluşturdukları ve "Zirve" kategorisi altında yer alan metaforlara Tablo 2'de yer verilmiştir.

Tablo 2. Öğretmen adaylarının zirve kategorisine ilişkin metaforları

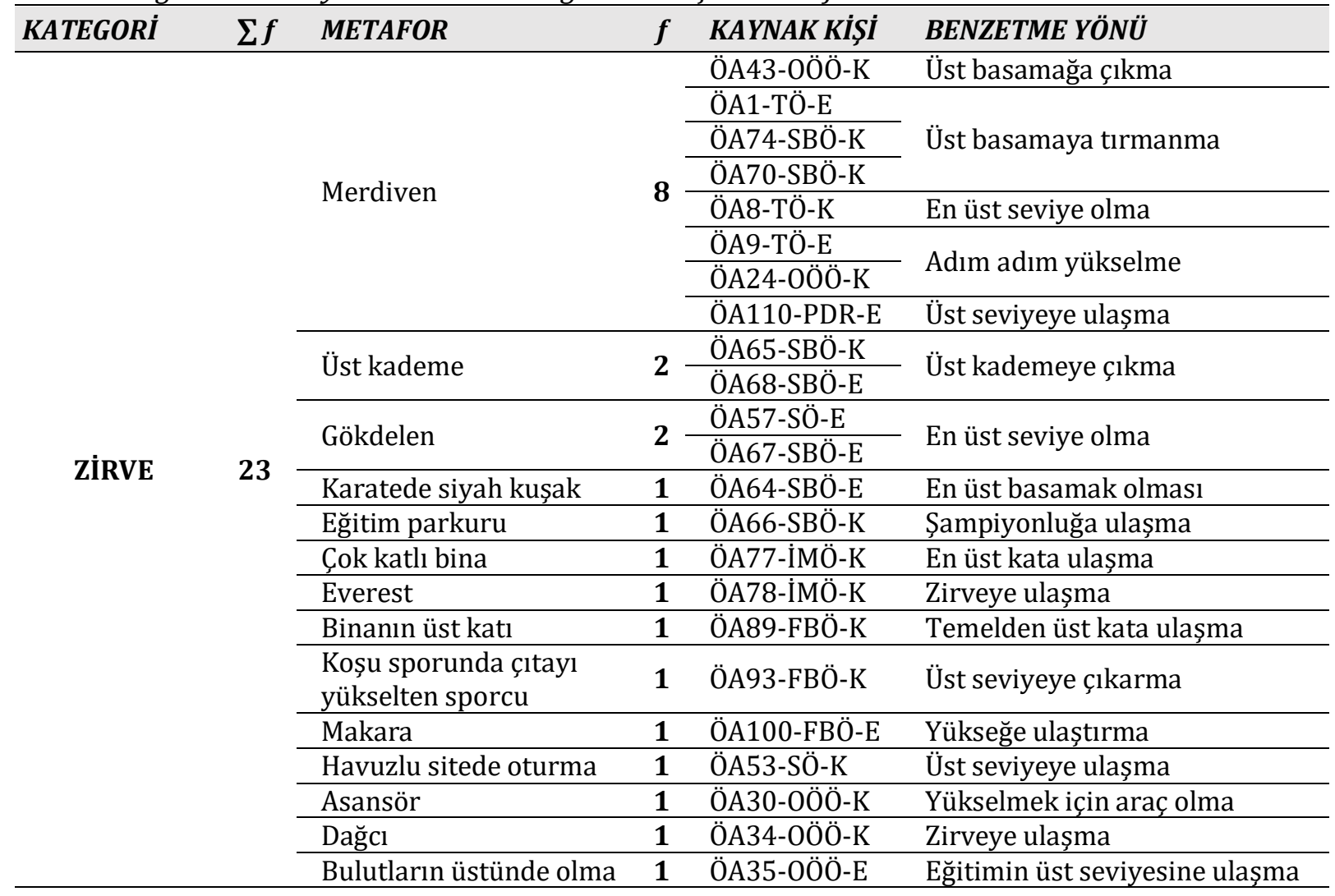

En çok yükleme yapılan 2. sıradaki kategori "Zirve" kategorisidir. Tablo 2 incelendiğinde; "Zirve" kategorisinin oluşmasına kaynaklık eden 23 öğretmen adayının 14 farklı metafor geliştirdiği görülmektedir. Bu metaforlar; merdiven, üst kademe, gökdelen, karatede siyah kuşak, eğitim parkuru, çok katlı bina, everest, binanın üst katı, koşu sporunda çıtayı yükselten sporcu, makara, havuzlu sitede oturma, asansör, dağcl ve bulutların üstünde olma metaforlarıdır. $\mathrm{Bu}$ kategoriye ilişkin öğretmen adaylarının verdikleri cevaplardan örnek ifadelere aşağıda yer verilmiștir. Lisansüstü eğitimi üst seviyeye, zirveye ulașma olarak gören öğretmen adaylarından biri (ÖA110-PDR-E) "Lisansüstü eğitim merdivene benzer; çünkü iyi bir kariyere ulaşmak için bu merdivenin basamaklarını sorunsuz çıkıp, adım adım zirveye yükselirler." diyerek, bir diğer öğretmen adayı (ÖA100-FBÖ-E) "Lisansüstü eğitim makaraya benzer; çünkü makaralar, cisimleri hareket ettirmekte kuvvet kazancı sağlayan, kuvvetin yönünü değiştiren basit makinelerdir. Lisansüstü eğitim de var olan lisans eğitimini yükselten, var olan gücü en yukarı seviyeye çıkaran, 
farkındalık yaratan ve insan hayatının yönünü değiștiren eğitimdir." diyerek zirve kategorisinin oluşmasına kaynaklık etmiştir. Lisansüstü eğitimi en üst seviye olarak gören öğretmen adaylarından biri (ÖA64-SBÖ-E) "Lisansüstü eğitim karatede siyah kuşak kademesine benzer; çünkü siyah kuşakta, lisansüstü eğitimde en üst basamakta eğitimlerin verildiği kademelerdir." sözleri ile diğeri ise (ÖA57-SÖ-E) "Lisansüstü eğitim gökdelene benzer çünkü binaların en güzeli ve yükseği, sürekli yüksekte kalır, diğerlerine benzemez." sözleriyle zirve kategorisi içerinde yer almıştır.

\section{Değer Kategorisine İliş̧kin Bulgular}

Öğretmen adaylarının lisansüstü eğitim kavramına ilişkin oluşturdukları ve "Değer" kategorisi altında yer alan metaforları Tablo 3'te sunulmuştur.

Tablo 3. Öğretmen adaylarının değer kategorisine ilişkin metaforları

\begin{tabular}{|c|c|c|c|c|c|}
\hline KATEGORI & $\sum f$ & METAFOR & $f$ & KAYNAK KISSSI & BENZETME YÖNÜ \\
\hline \multirow{13}{*}{ DEĞER } & \multirow{13}{*}{17} & Yaş pasta kreması & 2 & $\begin{array}{l}\text { ÖA84-İMÖ-K } \\
\text { ÖA33-0ÖÖ-K }\end{array}$ & $\begin{array}{l}\text { Alınan eğitimin daha } \\
\text { güzellesmesi }\end{array}$ \\
\hline & & & & ÖA90-FBÖ-E & Tercih edilmeyi artırma \\
\hline & & Pastanın ustundeki çilek & 2 & ÖA19-TÖ-E & Değerine değer katma \\
\hline & & Pasta süsü & 2 & $\begin{array}{l}\text { ÖA50-SÖ-K } \\
\text { ÖA7-TÖ-K }\end{array}$ & Değer katma \\
\hline & & Mücevher & 2 & $\begin{array}{l}\text { ÖA4-TÖ-E } \\
\text { ÖA20-TÖ-E }\end{array}$ & Değerine değer katma \\
\hline & & Elmas & 2 & $\begin{array}{l}\text { ÖA15-TÖ-E } \\
\text { ÖA109-PDR-K }\end{array}$ & Değerine değer katma \\
\hline & & Cila atma & 1 & ÖA83-İMÖ-K & Alınan eğitime değer katma \\
\hline & & Boyacı & 1 & ÖA55-SÖ-E & Alınan eğitime değer katma \\
\hline & & $\begin{array}{l}\text { Kadayıf tatlısının } \\
\text { üstündeki kaymak }\end{array}$ & 1 & ÖA56-SÖ-K & Alınan eğitime değer katma \\
\hline & & Taşlama tezgâhı & 1 & ÖA60-SÖ-K & Değer katma \\
\hline & & $\begin{array}{l}\text { Bir sayısının ardındaki } \\
\text { sifırlar }\end{array}$ & 1 & ÖA25-OÖÖ-K & Eğitime değer katma \\
\hline & & Fırında sütlaç & 1 & ÖA42-0ÖÖ-K & Eğitime değer katma \\
\hline & & Makyaj & 1 & ÖA111-PDR-K & Değerine değer katma \\
\hline
\end{tabular}

Tablo 3'te "Değer" kategorisinin oluşmasına kaynaklık eden 17 öğretmen adayının 12 farklı metafor geliştirdiği görülmektedir. Bu metaforlar; yaş pasta kreması, pastanın üstündeki çilek, pasta süsü, mücevher, elmas, cila atma, boyacı, kadayıf tatlısının üstündeki kaymak, taşlama tezgâhı, bir sayısının ardındaki sıfırlar, firında sütlaç ve makyaj metaforlarıdır. "Değer" kategorisine kaynaklık eden öğretmen adaylarının ifadelerinden örneklere aşă̆ıda yer verilmiştir. Lisansüstü eğitimi tercih edilmeyi artırma olarak ifade eden bir öğretmen adayı (ÖA19-TÖ-E) "Lisansüstü eğitim pasta üzerindeki çileğe benzer; çünkü bir lisans programı okumak damağımızda tarifi zor bir tat bırakır. Lisansüstü eğitim bu şölenin ikinci bölümüdür bence. Pastanın üstündeki çilek pastanın albenisini artırır." söyleriyle düşüncesini dile getirirken, değerine değer katma olarak ifade eden bir başka öğretmen adayı (ÖA25-00̈0̈-K) "Lisansüstü eğitim bir sayısının ardındaki sıfırlara benzer; çünkü öncesinde aldığımız eğitim birin kendisini oluşturur. Bir olmadan diğer sıfırların hükmü yoktur. Aldığımız her lisansüstü eğitimde bu sıfirlara yenilerini ekler ve sayının değerini arttırdığı gibi insan yaşamındaki statümüzü yasama kalitemizi artırır." Sözleriyle, bir diğer öğretmen adayı ise (ÖA15-TÖ-E) "Lisansüstü eğitim elmasa benzer; çünkü elmas madenden çıkarıldığında da değerlidir. Usta ellerde değerine değer katacak işçilik için belirli zamana ihtiyacı vardır. Bu zaman diliminde lisansüstü eğitim alan öğrenciler usta ellerde (değerli hocaların ellerinde) değerine değer katacak bilgi ve birikime ulaşacaklardır." sözleriyle görüşlerini belirtmişlerdir. 


\section{Zor Kategorisine İlişkin Bulgular}

Öğretmen adaylarının lisansüstü eğitim kavramına ilişkin oluşturdukları ve "Zor" kategorisi altında yer alan metaforlar Tablo 4'te yer almaktadır.

Tablo 4. Öğretmen adaylarının zor kategorisine ilișkin metaforları

\begin{tabular}{|c|c|c|c|c|c|}
\hline KATEGORI & $\sum f$ & METAFOR & $f$ & $\begin{array}{l}\text { KAYNAK } \\
\text { KISSII }\end{array}$ & BENZETME YÖNÜ \\
\hline \multirow{12}{*}{ ZOR } & \multirow{12}{*}{12} & Labirent & 1 & ÖA63-SBÖ-E & Zor bir süreç olma \\
\hline & & Engel & 1 & ÖA85-İMÖ-E & Ulaşılması zor \\
\hline & & Gökyüzü & $\mathbf{1}$ & ÖA91-FBÖ-E & Erişilmesi zor olma \\
\hline & & Șair & 1 & ÖA49-SÖ-E & Herkesin yapamayacağı bir șey olma \\
\hline & & Bitmeyen bir kazak & 1 & ÖA26-0ÖÖ-K & Zor bir süreç olma \\
\hline & & Uzaya çıkma & $\mathbf{1}$ & ÖA37-0ÖÖ-K & Zor aşamaları olma \\
\hline & & $\begin{array}{l}\text { Endemik bitki yetiştiren } \\
\text { botanik bahçe }\end{array}$ & 1 & ÖA5-TÖ-K & Herkesin yapamayacağı \\
\hline & & Denizdeki inci & 1 & ÖA11-TÖ-K & Ulașılmasının zor olması \\
\hline & & Mayın tarlası & $\mathbf{1}$ & $\begin{array}{l}\text { ÖA107-PDR- } \\
\text { E }\end{array}$ & Engelleri așma \\
\hline & & Dik bir yokuş & 1 & $\begin{array}{l}\text { ÖA108-PDR- } \\
\text { E }\end{array}$ & Zahmetli olma \\
\hline & & Profesyonel uçușlar & 1 & ÖA6-TÖ-E & Cesaret gerektiren zor bir süreç olma \\
\hline & & Yıldız & 1 & ÖA75-SBÖ-E & Ulaşılması zor \\
\hline
\end{tabular}

Tablo 4'te görüldüğü gibi, "Zor" kategorisinin oluşmasını kaynaklık eden 12 öğretmen adayı 12 farklı metafor geliștirmiştir. Bu metaforlar; labirent, engel, gökyüzü, şair, bitmeyen bir kazak, uzaya çıkma, endemik bitki yetiştiren botanik bahçe, denizdeki inci, mayın tarlası, dik bir yokuş, profesyonel uçuşlar ve yıldız metaforlarıdır. Bu kategoriye kaynaklık eden öğretmen adaylarının verdikleri cevaplardan örnek ifadelere aşağıda yer verilmiştir. Lisansüstü eğitimi zor bir süreç olarak ifade eden bir öğretmen adayı (ÖA63-SBÖ-E) "Lisansüstü eğitim labirente benzer; çünkü zor ve karmaşık bir süreçtir. Çıkabildiğin vakit ise rahata kavuşabilirsin."diyerek, bir başka öğretmen adayı ise (ÖA26-00̈Ö-K) "Lisansüstü eğitim örmeye başladığın ama bitiremediğin bir kazağa benzer; çünkü başta kolay gelir bitiriverecekmişsin gibi başlarsın ama bir türlü bitmez. Arada bir de ilmek kaçırırsın geri sökersin ve yanıldı̆̆ın yerden tekrar başlarsın. Lisansüstü eğitimde buna benzer. Dışarıdan kolay gibi gelir başlarsın ama işin içinden zor çıkarsın. Uğraşıp tezini yazarsın ama beğenilmezse geri en baștan başlar tekrar yazmaya devam edersin. Ama kazak bitince o aldığın keyif ve kendinle gurur duymada paha biçilemez." diyerek zor kategorisinin oluşmasına kaynaklık etmiştir. Bir başka öğretmen adayı ise (ÖA11-TÖ-K) "Lisansüstü eğitim denizdeki inciye benzer; çünkü ulaşması çok güçtür. Gidilen yol da epey yorucudur. Ancak ulaşıldığında değerine paha biçilmez" sözleriyle lisansüstü eğitimin ulaşılması zor ancak ulaşıldığında değerinin tartışılmaz olduğuna vurgu yapmıştır. Zor kategorisi içerisinde yer alan bir başka öğretmen adayı (ÖA107-PDR-E) "Lisansüstü eğitim mayın tarlasına benzer; çünkü lisansüstü eğitim bir hedeftir. Bu hedefe ulaşabilmek için birçok zorluk vardır bu tarlada ne çok hızlı ilerlemek lazım ne de çokyavaş ilerlemek gerekir. En önemli unsur mayın tarlasında emin adımlarla ilerlemektir." şeklindeki görüşüyle lisansüstü eğitimin engellerle dolu olduğu ve bu süreçte dikkatli ilerlenmesi gerektiği üzerinde durmuştur.

\section{Çaba Kategorisine İlişkin Bulgular}

Öğretmen adaylarının lisansüstü eğitim kavramına ilişkin oluşturdukları ve "Çaba" kategorisi altında yer alan metaforlara Tablo 5 'te yer verilmiştir. 
Tablo 5. Öğretmen adaylarının çaba kategorisine ilişskin metaforları

\begin{tabular}{|c|c|c|c|c|c|}
\hline KATEGORI & $\overline{\sum f}$ & METAFOR & $f$ & KAYNAK KISSİ & BENZETME YÖNÜ \\
\hline \multirow{7}{*}{ ÇABA } & \multirow{7}{*}{8} & Arl & 2 & $\begin{array}{l}\text { ÖA76-İMÖ-K } \\
\text { ÖA3-TÖ-E }\end{array}$ & Çok çalışma \\
\hline & & & & ÖA2-TÖ-K & Azimle çok çalıșma \\
\hline & & Karınca & 2 & ÖA48-SÖ-K & Sürekli çalıșma \\
\hline & & Fazla mesai yapma & $\mathbf{1}$ & ÖA28-0ÖÖ-K & Cok çalıșma \\
\hline & & Süresiz öğrencilik & 1 & ÖA46-SÖ-K & Sürekli çalıșma \\
\hline & & Tırtılı kelebeğe dönüșme hikâyesi & 1 & ÖA10-TÖ-K & Çok çalıșma, sabretme \\
\hline & & Köprü & 1 & ÖA14-TÖ-K & Hedefe ulaşma için çabalama \\
\hline
\end{tabular}

Tablo 5 incelendiğinde; "Çaba" kategorine kaynaklık eden 8 öğretmen adayının arı, karınca, fazla mesai yapma, süresiz öğrencilik, tırtılı kelebeğe dönüşme hikâyesi ve köprü olmak üzere 6 farklı metafor geliştirdiği görülmektedir. Bu kategoriye ilişkin öğretmen adaylarının verdikleri cevaplardan örnek ifadelere aşağıda yer verilmiştir. Lisansüstü eğitimi çok çalışma ve çabalama ile özdeşleștiren öğretmen adaylarından biri (ÖA76-İMÖ-K) "Lisansüstü eğitim arıya benzer; çünkü arının bal yapabilmesi için çok büyük çaba göstermesi ve çalışması gerekir. Lisansüstü eğitim yapılabilmesi içinde arı gibi azimle çok çalışmak gerektir." diyerek, bir diğeri (ÖA48-SÖ-K) "Lisansüstü eğitim ağustos böceği ile karınca hikâyesindeki karıncaya benzer; çünkü lisansüstü eğitim için çok çalışmak gerekir sadece not ortalamamızı yüksek tutmamız yetmez, ALES'ten de yüksek puan almalıyız. Peki bu yeter mi? Hayır. Lisansüstü eğitim yapılan süre içinde de çok çalışmamız gerekir.", diyerek, bir başka öğretmen adayı ise (ÖA46-SÖ-K) "Lisansüstü eğitim süresiz öğrenciliğe benzer; çünkü hep sınavlara çalışmak zorundadır. Yükselme sınavlarına girer sürekli. Tez yazar, makale yazar, kitap yazar, İngilizce makale yazar... Ingilizce demişsen, iyi bir mevkiye gelmesi için İngilizcesinin çok iyi olması gerekir. Yüksek bir motivasyona sahip olması gerekir. Yılmadan devam edecek bir güç gerekir." diyerek çaba kategorisinin oluşmasına kaynaklık etmiştir.

\section{Uzmanlık Kategorisine İlişkin Bulgular}

Öğretmen adaylarının lisansüstü eğitim kavramına ilişkin oluşturdukları ve "Uzmanlık" kategorisi altında yer alan metaforlara Tablo 6'da yer verilmiştir.

Tablo 6. Öğretmen adaylarının uzmanlık kategorisine ilişsin metaforları

\begin{tabular}{|c|c|c|c|c|c|}
\hline KATEGORI & $\sum f$ & METAFOR & $f$ & KAYNAK KISSII & BENZETME YÖNÜ \\
\hline \multirow{6}{*}{ UZMANLIK } & \multirow{6}{*}{6} & Gübreli domates & 1 & ÖA73-SBÖ-K & Uzmanlaşma \\
\hline & & Uzman doktor & 1 & ÖA82-İMÖ-K & Alanda uzmanlașma \\
\hline & & Final maçı & 1 & ÖA45-SÖ-K & Uzmanlaşmak için son adım olma \\
\hline & & Ustalık & $\mathbf{1}$ & ÖA52-SÖ-K & Alanında uzmanlașma \\
\hline & & Ansiklopedi & 1 & ÖA23-0ÖÖ-K & Fazla bilgi sahibi olma \\
\hline & & Profesyonel sporculuk & 1 & ÖA31-0ÖÖ-K & Profesyonelleșme aşaması olma \\
\hline
\end{tabular}

Tablo 6 incelendiğinde; "Uzmanllk" kategorine kaynaklık eden 6 öğretmen adayının gübreli domates, uzman doktor, final maçl, ustalık, ansiklopedi ve profesyonel sporculuk olmak üzere 6 farklı metafor geliştirdiği görülmektedir. Uzmanlık kategorisine kaynaklık eden öğretmen adaylarının ifadelerinden örneklere aşağıda yer verilmiştir. Lisansüstü eğitim kavramını alanında uzmanlaşma olarak gören bir öğretmen adayı (ÖA45-SÖ-K) "Lisansüstü eğitim final maçına benzer; çünkü geleceğimizi final maçı belirler. Artık biz bir alan belirlemişizdir ve bu konu hakkında uzmanlaşmak için eğitim alacağız. Bu da final maçına çıkacağız anlamına gelir. Lisansüstü eğitimi tamamlamak da final maçını seçmek yani seçtiğimiz alanda uzman olmaktır." sözleriyle, bir başka öğretmen adayı ise (ÖA31-00̈Ö-K) "Lisansüstü eğitim profesyonel sporculuğa benzer; çünkü lisansüstü eğitim öğrencileri, yıllarını harcayarak bir alanda edindikleri bilgi ve birikimlerinin daha da ayrıntılarına inerek, hâkim oldukları konularda uzman olabilmek için daha ince düşünüp, daha fazla araştırma yaparak profesyonelleșmeye başladıkları eğitim aşamasındadırlar." sözleriyle uzmanlık kategorisine kaynaklık etmiştir. 


\section{Keşif-Araştırma Kategorisine İliş̧kin Bulgular}

Öğretmen adaylarının lisansüstü eğitim kavramına ilişkin oluşturdukları ve "KeşifAraştırma" kategorisi altında yer alan metaforlar Tablo 7'de sunulmuştur.

Tablo 7. Öğretmen adaylarının keşif-araştırma kategorisine iliş̧kin metaforları

\begin{tabular}{|c|c|c|c|c|c|}
\hline KATEGORI & $\sum f$ & METAFOR & $f$ & KAYNAK KISȘI & BENZETME YÖNÜ \\
\hline \multirow{6}{*}{$\begin{array}{c}\text { KEŞIF- } \\
\text { ARAŞTIRMA }\end{array}$} & \multirow{6}{*}{6} & \multirow{2}{*}{ Uzay } & \multirow{2}{*}{2} & ÖA80-İMÖ-K & Bilinmeyenleri bulma \\
\hline & & & & ÖA59-SÖ-K & Keșif süreci olma \\
\hline & & Uzaya yapılan yolculuk & 1 & ÖA86-İMÖ-K & Keşfetme \\
\hline & & Arkeolog & $\mathbf{1}$ & ÖA18-TÖ-K & Derinlemesine araștırma yapma \\
\hline & & Özel dedektif & 1 & ÖA51-SÖ-K & Araştırma yapma \\
\hline & & Araștırmacl & $\mathbf{1}$ & ÖA61-SÖ-K & Sürekli araștırma yapma \\
\hline
\end{tabular}

Tablo 7'de "Keşif-Araştırma" kategorisinin oluşmasına kaynaklık eden 6 öğretmen adayının 5 farklı metafor geliştirdiği görülmektedir. Bu metaforlar; uzay, uzaya yapılan yolculuk, arkeolog, özel dedektif ve araştırmacı metaforlarıdır. Bu kategorisine kaynaklık eden öğretmen adaylarının ifadelerinden örnekler aşağıda yer almaktadır. Lisansüstü eğitimi keşfetme süreci olarak ifade eden bir öğretmen adayı (ÖA86-їMÖ-K) "Lisansüstü eğitim uzaya yapılan yolculuğa benzer; çünkü bu eğitime başlandığında kimsenin bulamadı̆̆ı henüz keşfedilmemiş şeylerle karşılaşılabilir." diyerek, benzer şekilde araştırma ve bilinmeyenleri keşfetme olarak gören bir başka öğretmen adayı ise (ÖA18-TÖ-K) "Lisansüstü eğitim arkeoloğa benzer; çünkü arkeolog yerin derinliklerine inerek değerli taşlar eserler bularak alanında başarılı olur. Lisansüstü eğitim de aynı şekildedir. Bilginin derinliklerine inerek araştırarak farklı yollardan fikirler edinir böylece alanında bilinmeyenleri gün yüzüne çıkarır". diyerek keşif-araştırma kategorisi içerisinde yer almıştır.

\section{Yol Gösterici Kategorisine İlişkin Bulgular}

Öğretmen adaylarının lisansüstü eğitim kavramına ilişkin oluşturdukları ve "Yol gösterici" kategorisi altında yer alan metaforlar Tablo 8'de yer almaktadır.

Tablo 8. Öğretmen adaylarının yol gösterici kategorisine ilișkin metaforları

\begin{tabular}{|c|c|c|c|c|c|}
\hline KATEGORI & $\sum f$ & METAFOR & $F$ & KAYNAK KIŞİ & BENZETME YÖNÜ \\
\hline \multirow{5}{*}{ YOL GÖSTERICİ } & \multirow{5}{*}{$\mathbf{5}$} & Ișık & 1 & ÖA79-İMÖ-K & İnsanları aydınlatma \\
\hline & & Hazırlık maçı & 1 & ÖA94-FBÖ-K & Yol gösterici bir süreç olma \\
\hline & & Nakış eğitmeni & 1 & ÖA36-OÖÖ-K & Yol gösterici olma \\
\hline & & Usta-çırak ilișkisi & 1 & ÖA38-0ÖÖ-K & Başkasını yetiștirme \\
\hline & & Rota & 1 & ÖA102-PDR-E & Gidilecek yolu gösterme \\
\hline
\end{tabular}

Tablo 8 incelendiğinde; "Yol gösterici” kategorine kaynaklık eden 5 öğretmen adayının ışık, hazırlık maçı, nakış eğitmeni, usta-çırak ilişkisi ve rota olmak üzere 5 farklı metafor geliştirdiği görülmektedir. Bu kategoriye kaynaklık eden öğretmen adaylarının ifadelerinden örneklere aşağıda yer verilmiştir.

Lisansüstü eğitim için usta-çırak metaforunu kullanan bir öğretmen adayı (ÖA38-00̈Ö-K) "Lisansüstü eğitim usta-çırak ilişskisine benzer; çünkü usta kendi mutfağında en az kendisi kadar bilgili ve yetenekli birini yetiştirir. Kendisinden sonraki ustayı yetiştirir." diyerek, nakış eğitmeni metaforunu kullanan bir başka öğretmen adayı ise (ÖA36-0öÖ-K) "Lisansüstü eğitim nakış eğitmenine benzer. Çünkü eğitmen artık kendi kanaviçelerini işlemiş, gereken eğitimlerini almış ve artık uzmanlaşma yolunda ilerliyordur. Bu yolda ilerlerken de çocuklara rehber olabilecek, onları ilmek ilmek işleyebilecek yeni öğretmenler yetiştirecektir. Meslek sırlarını yeni nesil öğretmenlerle paylaşacaktır." diyerek yol gösterici kategorisinin oluşmasına kaynaklık etmiştir. Lisansüstü eğitimde hazırlık maçı metaforunu kullanan bir öğretmen adayı ise (ÖA94-FBÖ-K) "Lisansüstü eğitim hazırlık maçına benzer; çünkü hazırlık maçında göstereceğimiz performans bize asıl maçta ne yapabileceğimizi, eksiklerimizi, hatalarımızı gösterir."diyerek lisansüstü eğitim sürecinde yaşananların yol gösterici olacağına vurgu yapmıştır. 


\section{Doyumsuzluk Kategorisine İliş̧kin Bulgular}

Öğretmen adaylarının lisansüstü eğitim kavramına ilişkin oluşturdukları ve "Doyumsuzluk" kategorisi altında yer alan metaforlara Tablo 9'da yer verilmiştir.

Tablo 9. Öğretmen adaylarının doyumsuzluk kategorisine ilişskin metaforları

\begin{tabular}{|c|c|c|c|c|c|}
\hline KATEGORI & $\sum f$ & METAFOR & $f$ & KAYNAK KISSII & BENZETME YÖNÜ \\
\hline \multirow{5}{*}{ DOYUMSUZLUK } & \multirow{5}{*}{5} & Son model bir araba & 1 & ÖA98-FBÖ-E & Bilgiye doymama \\
\hline & & Emeklilik sonrası çalıșma & 1 & ÖA40-OÖÖ-K & Çalıșmaya doymama \\
\hline & & Tazmanya Canavarı & 1 & ÖA13-TÖ-K & Doyumsuz olma \\
\hline & & Ana yemek & 1 & ÖA22-TÖ-K & Doyumsuz olma \\
\hline & & $\begin{array}{l}\text { Çikolatalı pastaya } \\
\text { doyamama }\end{array}$ & 1 & ÖA112-PDR-K & Doyumsuz olma \\
\hline
\end{tabular}

Tablo 9'da "Doyumsuzluk" kategorisinin oluşmasına kaynaklık eden 5 öğretmen adayının 5 farklı metafor geliştirdiği görülmektedir. Bu metaforlar; son model bir araba, emeklilik sonrası çalışma, Tazmanya canavarı, ana yemek ve çikolatalı pastaya doyamama metaforlarıdır. Bu kategoriye ilişkin öğretmen adaylarının ifadelerinden örnekler aşağıda yer almaktadır. Lisansüstü eğitimi bilgiye doymama, sürekli öğrenme arzusu olarak ifade eden bir öğretmen adayı (ÖA13TÖ-K) "Lisansüstü eğitim Tazmanya canavarına benzer; çünkü on altı yıllık bir eğitim/öğretim hayatı onu doyurmamıştır. Hala okulun ilk günü kadar okumaya ve bilgi açlığını ifade eder. Dört yıllık akademik hayatındaki edindiği bilgiler ona yetmemiştir, daha fazla araştırıp sofradan tok bir şekilde kalkmaktır." sözleriyle, bir başka öğretmen adayı ise (0̈A40-00̈0̈-K) "Lisansüstü eğitim emeklilik sonrası çalışmaya benzer; çünkü lisans eğitimini tamamlamış insanların çoğu KPSS ile atanıp sadece mesleklerini ifa eden insanlarla doludur. Ancak lisansüstü eğitime devam eden insanlar lisans eğitimini bitirmiş olsa da okumaya doymayan, hem sürekli ögrenmek isteyen hem de öğretmek isteyen kişilerdir." sözleriyle bu kategorinin oluşmasına kaynaklık etmiştir.

\section{Üretim Kategorisine İlişkin Bulgular}

Öğretmen adaylarının lisansüstü eğitim kavramına ilişkin oluşturdukları ve "Üretim" kategorisi altında yer alan metaforlara Tablo 10'da yer verilmiştir.

Tablo 10. Öğretmen adaylarının üretim kategorisine ilişkin metaforları

\begin{tabular}{|c|c|c|c|c|c|}
\hline KATEGORI & $\sum f$ & METAFOR & $f$ & KAYNAK KIŞSI & BENZETME YÖNÜ \\
\hline \multirow{4}{*}{ ÜRETIM } & \multirow{4}{*}{4} & Mimarlık & 1 & ÖA88-İMÖ-K & Özgün șeyler üretme \\
\hline & & Meyve veren ağaç & $\mathbf{1}$ & ÖA99-FBÖ-K & Ürün verme \\
\hline & & Fabrika & $\mathbf{1}$ & ÖA16-TÖ-K & Yeni ürünler ortaya koyma \\
\hline & & Pasta malzemeleri & $\mathbf{1}$ & ÖA101-PDR-K & Yeni ürün ortaya koyma \\
\hline
\end{tabular}

Tablo 10 incelendiğinde; "Üretim" kategorine kaynaklık eden 4 öğretmen adayının mimarlık, meyve veren ağaç, fabrika ve pasta malzemeleri olmak üzere 4 farklı metafor geliştirdiği görülmektedir. Bu kategoriye kaynaklık eden öğretmen adaylarının ifadelerinden örneklere aşağıda yer verilmiștir. Lisansüstü eğitime ilișkin özgün ve yeni ürünler yaratma olarak mimarlık metaforunu kullanan bir öğretmen adayının (ÖA88-IMÖ̈-K) "Lisansüstü eğitim mimarlı̆ga benzer; çünkü mimarlar güzel olanı daha güzel hale getirir. Güzel tasarımlar yaparak farklı şeyler ortaya koyarlar. Özgün yapıtlar ortaya çıkar. Ortada bir şeyler vardır var olan şeyleri daha estetik hale getirir daha göz alıcı hala getirir." sözleri ile fabrika metaforunu kullanan bir başka öğretmen adayının (ÖA16-TÖ-K) "Lisansüstü eğitim fabrikaya benzer; çünkü fabrikalar yeni ürünleri piyasaya sürerken, lisansüstü eğitim de fabrikalar gibi ortaya çıkan yeni ve özgün bilgileri insanların kullanımına sunar." sözleri üretim kategorisi içerisinde yer alan görüşlerdendir. 


\section{SONUÇLAR, TARTIŞMA VE ÖNERILLER}

Araştırma sonucunda; 112 öğretmen adayı 93 farklı metafor geliştirmiş ve bu metaforlar "Gelişim", "Zirve", "Değer", "Zor", "Çaba", "Uzmanlık", Keşif-Araştırma", "Yol Gösterici", Doyumsuzluk" ve "Üretim" olmak üzere 10 kategoride toplanmıştır. Gömleksiz ve Et (2013) tarafından yapılan Fırat Üniversitesi Eğitim Fakültesi öğrencileri üzerinde yürütülen benzer araştırmada da oluşturulan 80 metafor 11 olumlu, 4 olumsuz kategori olmak üzere toplam 15 kategori de toplanmıştır. Olumlu kategoriler zirve, uzmanlık, umut, popülerlik, statü, kariyer, başarı, araştırma, yol göstericilik, çaba, güç; olumsuz kategoriler ise kayırmacılık, yanılgı, umutsuzluk, baskı ve sindirme kategorileridir. Her iki araştırma sonucu karşılaştırıldığında; zirve, uzmanlık, keşif-araştırma (araştırma), yol gösterici, çaba, zor (güç) kategorilerinin ortak olduğu tespit edilmiştir.

Araştırma sonucunda; en çok yükleme yapılan kategorinin Gelişim kategorisi olduğu ve bu kategoriye 26 öğretmen adayının 25 farklı metafor (tereyağlı ekmeğin üstündeki bal, merdiven, yeni sürüm teknolojik alet, çorba malzemelerinden biri, yeni yapılan bina, dalda kalan son elma, aile, insanın yaşlanması, yeni model saat, ağaca aşı yapma, yazarlık yapma, yarışma, kirazın olgunlaşması, sağlam binaya kat çıkma, kütüphane, çok kitap okuma, papağan, fidanın ağaç olması, meyve, ekonomik büyüme, ağacın dalları, değerli taşları işleme, pokemon, kitap, aşçı) geliştirdiği tespit edilmiştir. Gömleksiz ve Yıldırım (2013) tarafından lisansüstü eğitim alan öğrencilerin lisansüstü eğitime ilişkin görüşlerinin alındığı nitel araştırmada "Çalışma alanında kendini geliştirmek", "Donanımlı birey olmak”, "Meslekteki gelişimini sağlamak”, "Alanla ilgili gelişmeleri takip etmek, "Kendini geliştirme isteği" kategorileri mevcut araştırmanın Gelişme kategorisine ilişkin oluşturulan metoforların gerekçeleriyle paralellik göstermektedir. Benzer şekilde, Şahin, Demir ve Arcagök (2015) tarafından öğretmen adaylarının lisansüstü öğretime yönelik görüşlerinin ortaya konduğu araştırmada, lisansüstü eğitimi düşünme nedenleri arasında hem mesleki hem de akademik gelişime katkısına vurgu yapmaktadır. Şaşmaz Ören, Yılmaz ve Güçlü'nün (2012) araştırmasında öğretmen adaylarının lisansüstü eğitim görmeyi gelişim ile ilişkilendirdiklerini belirtmesi de mevcut sonucu desteklemektedir. Aslan (2010) tarafından yapılan araştırmada da lisansüstü öğrenim gören öğrencilerin lisansüstü öğrenime başlama nedenleri olarak, çalıştıkları alanda kendilerini bireysel ve toplumsal yönlerden geliştirmek/yetkinleștirmek, bilimsel anlayış ve yaklaşımın ne olduğunu öğrenmek ve öğretmek, kariyerde yükselmek, yenilik ve gelişmeleri akademik bir disiplin içerisinde izlemek, sunduğu dersin niteliğini artırarak öğrencilerine daha yararlı olabilmek ve bilimsel çalışmalar yapmak için tercih ettiklerini belirtmeleri lisansüstü eğitim ile gelişim kategorini özdeşleşmesini desteklemektedir. Alabaş, Kamer ve Polat'ın (2012) kariyer gelişimlerinde lisansüstü eğitim üzerine öğretmenlerin görüşlerini aldıkları araştırmasında ve Başer, Narlı ve Günhan'ın (2005) yine öğretmenlerin lisansüstü eğitimden beklentilerini ortaya koyduğu araştırmasında öğretmenlerin kendilerini geliştirmek için lisansüstü eğitimi tercih ettiklerini belirtmeleri lisansüstü eğitim kavramının gelişim kategorisi ile örtüşen bir diğer sonuçtur.

Zirve kategorisine ilişkin sonuç incelendiğinde; 23 öğretmen adayının 14 farklı metafor (merdiven, üst kademe, gökdelen, karatede siyah kuşak, eğitim parkuru, çok katlı bina, everest, binanın üst katı, koşu sporunda çıtayı yükselten sporcu, makara, havuzlu sitede oturma, asansör, dağcl, bulutların üstünde olma) geliştirdiği görülmektedir. Gömleksiz ve Et (2013) tarafından yapılan araştırmada da zirve kategorisine ilişkin 9 farklı metafor geliştirmiş ve bu metaforlardan dağa tırmanma, gökdelen, apartmanın en üst katı ve Everest metaforlarının mevcut araştırma sonuçlarıyla benzerlik gösterdiği tespit edilmiştir. Gömleksiz ve Yıldırım'ın (2013) araştırmasında lisansüstü eğitim alan öğrencilerin lisansüstü eğitime ilişkin görüşleri arasında yer alan "Kariyer yapıp yükselmek" kategorisi mevcut araştırmanın zirve kategorisine ilişkin oluşturulan metaforların gerekçeleriyle örtüşmektedir. Şaşmaz Ören, Yılmaz ve Güçlü’nün (2012) araştırmasında öğretmen adaylarının lisansüstü eğitim görmeyi kariyer kategorisinde yer alan "Alanımda yükselmek", "Daha üst bir kariyer düzeyine çıkmak", "Öğretmenlikten daha yüksek bir kariyer yapmak" gibi kodlamalar ile ilişkilendirdiklerini belirtmesi de mevcut araştırmanın zirve kategorisine ilişkin gerekçelerle paralellik göstermektedir. 
Bir diğer kategori olan Değer kategorisine ilişkin sonuca bakıldığında; 17 öğretmen adayının 12 farklı metafor (yaş pasta kreması, pastanın üstündeki çilek, pasta süsü, mücevher, elmas, cila atma, boyacı, kadayıf tatlısının üstündeki kaymak, tașlama tezgâhı, bir sayısının ardındaki sıfırlar, fırında sütlaç, makyaj) geliştirdiği görülmektedir. Gömleksiz ve Et'in (2013) araştırmasında popülerlik kategorinde yer alan krema metaforu son şeklini alıp güzelleşme gerekçesiyle, mevcut araştırmada bu kategori de yer alan yaş pasta kreması metaforu alınan eğitimin daha güzelleşmesi gerekçesiyle paralellik göstermektedir. Benzer şekilde Gömleksiz ve Et'in (2013) araştırmasında yine popülerlik kategorinde yer alan değerli aksesuar metaforu, mevcut araştırmada bu kategori de yer alan elmas ve mücevher metaforlarılyla değerine değer katma gerekçesiyle örtüşmektedir.

Zor kategorisine ilişkin sonuç incelendiğinde; 12 öğretmen adayının 12 farklı metafor (labirent, engel, gökyüzü, şair, bitmeyen bir kazak, uzaya çıkma, endemik bitki yetiştiren botanik bahçe, denizdeki inci, mayın tarlası, dik bir yokuş, profesyonel uçuşlar, yıldız) geliştirdiği görülmektedir. Gömleksiz ve Et (2013) tarafından yapılan araştırmada zor kategorisine eş anlamlı güç kategorisi oluşturulmuş ve güç kategorisine ilişkin 3 farklı metafor geliştirmiş̦tir. Her iki araştırmada yer alan engel metaforunun bu kategori için ortak metafor olduğu sonucuna ulaşılmıştır. Şaşmaz Ören, Yılmaz ve Güçlü'nün (2012) araştırmasında da, öğretmen adaylarının lisansüstü eğitim görmeyi istememelerine ilişkin oluşan kategori zorluk inancı kategorisidir. Araştırmacıların bu kategoride yer alan "Şartları zor", "Uğraşmak zor", Lisansüstü eğitim zor" gibi kodlamaların lisansüstü eğitim ile ilişkilendirildiğini belirtmesi de mevcut araştırmanın zor kategorisine ilişkin gerekçelerle paralellik göstermektedir.

Araştırma sonuçlarından biri de Çaba kategorine ilişkin sonuçtur. Bu kategoriyi oluşturan 8 öğretmen adayının 6 farklı metafor (arı, karınca, fazla mesai yapma, süresiz öğrencilik, tırtılı kelebeğe dönüşme hikâyesi, köprü) geliştirdiği tespit edilmiştir. Gömleksiz ve Et'in (2013) araştırmasında da Çaba kategorisi altında mevcut araştırma sonuçlarıyla paralellik gösteren arı ve karınca metaforlarının yer aldığı belirlenmiş; gerekçesinde ise çok çalışma vurgulanmıştır.

Bir diğer kategori olan Uzmanlık kategorisine ilişkin sonuca bakıldığında; 6 öğretmen adayının 6 farklı metafor (gübreli domates, uzman doktor, final maçı, ustalık, ansiklopedi, profesyonel sporculuk) geliştirdiği görülmektedir. Gömleksiz ve Et'in (2013) araștırmasında da öğrenciler uzmanlık kategorisi altında 13 farklı metafor ortaya koymuşlardır. Mevcut araştırmada yer alan alanında uzmanlaşma gerekçesiyle ustalık metaforunun, Gömleksiz ve Et (2013) tarafından yapılan araştırmadaki alanında donanım gerektirmesi gerekçesiyle usta metaforu ile birebir örtüştüğü tespit edilmiştir. Gömleksiz ve Yıldırım (2013) tarafından lisansüstü eğitim alan öğrencilerle yürütülen araştırmada yer alan "Akademik bilgi ve yeterlilik" kategorisi, mevcut araştırmanın uzmanlık kategorisine ilişkin oluşturulan metaforların gerekçeleriyle benzerlik gösterdiği söylenebilir. Ayrıca İyibil ve Akpınar'ın (2013) araştırmasında yer alan öğretmen adaylarının \%36'sının lisansüstü eğitimi bir alanda uzmanlaşmak olarak algıladığı sonucu mevcut araştırma sonucunu desteklemektedir. Benzer şekilde Şahin, Demir ve Arcagök (2015) tarafından yapılan araştırmada ve Şaşmaz Ören, Yılmaz ve Güçlü'nün (2012) araştırmasında öğretmen adaylarının lisansüstü eğitim görmeyi uzmanlık ile ilişkilendirdiklerini belirtmesi de mevcut araştırma sonucunu desteklemektedir. Alabaş, Kamer ve Polat'ın (2012) kariyer gelişimlerinde lisansüstü eğitim üzerine öğretmenlerin görüşlerini aldıkları araştırmada, öğretmenlerin "Belirli bir alanda uzmanlaşma isteği" nedeni ile lisansüstü eğitimi tercih ettiklerini ortaya koyması yine lisansüstü eğitim kavramının uzmanlık kategorisi ile paralellik gösteren bir sonuçtur.

Keşif-araştırma kategorisine ilişkin sonuç incelendiğinde; 6 öğretmen adayının 5 farklı metafor (uzay, uzaya yapılan yolculuk, arkeolog, özel dedektif ve araştırmacı) geliștirdiği tespit edilmiştir. Gömleksiz ve Et (2013) tarafından yapılan çalışmada da benzer şekilde araştırma kategorisi oluşturulduğu ve bu kategoriye ilişkin 2 farklı metafor (google ve düzenli çalışma) ortaya konulduğu tespit edilmiştir. Şahin, Demir ve Arcagök (2015) tarafından yapılan araştırmada da öğretmen adayları arasında lisansüstü eğitimin meslekte araştırma yapma olarak görülmesi sonucu mevcut araştırma sonucunu desteklemektedir.

Bir diğer kategori olan Yol gösterici kategorisine ilişkin sonuca bakıldığında; 5 öğretmen adayının 5 farklı metafor (ışık, hazırlık maçı, nakış eğitmeni, usta-çırak iliş̧isi ve rota) geliştirdiği belirlenmiștir. Gömleksiz ve Et'in (2013) araștırmasında da öğrenciler yol göstericilik kategorisi 
altında 3 farklı metafor (güneş, meyve verme, ışık) ortaya koymuşlardır Yapılan detaylı inceleme sonucunda; hem Gömleksiz ve Et'in (2013) araştırmasında hem de mevcut araştırmada yol göstericilik kategorisinde yer alan ışık metaforunun insanları aydınlatma gerekçesiyle ortak olduğu sonucuna ulaşılmıştır.

Araştırma sonucunda elde edilen bir diğer kategori Doyumsuzluk kategorisidir. $\mathrm{Bu}$ kategoriye ilişkin 5 öğretmen adayının 5 farklı metafor (son model bir araba, emeklilik sonrası çalışma, Tazmanya canavarı, ana yemek, çikolatalı pastaya doyamama) geliștirmiștir. Gömleksiz ve Yıldırım (2013) tarafından yapılan araştırmada lisansüstü eğitim alan öğrencilere lisansüstü eğitim almada etkili olan faktörlerin neler olduğu sorulmuş ve bu başlık altında "Eğitim sürecinden kopmamak" kategorisi oluşmuştur. Bu sonucun, mevcut araștırmanın doyumsuzluk kategorisine iliş̧kin oluşturulan metaforların bilgiye doymama, çalışmaya doymama ve doyumsuz olma gerekçeleriyle paralellik gösterdiği söylenebilir.

Araştırmada en az yükleme yapılan kategori Üretim kategoridir. Bu kategoriye ilişkin 4 öğretmen adayının 4 farklı metafor (mimarlık, meyve veren ağaç, fabrika, pasta malzemeleri) geliştirdiği sonucuna ulaşılmıștır. Gömleksiz ve Et'in (2013) araştırmasında başarı kategorinde yer alan üretim metaforu yeni fikirler üretilmesi gerekçesiyle, mevcut araştırmada bu kategori de yer alan metaforların gerekçesiyle birebir örtüşmektedir. Gömleksiz ve Yıldırım (2013) tarafından lisansüstü eğitim alan öğrencilerle yürütülen araştırma da "Alana katkıda bulunmak", "Üretken olma" kategorileri mevcut araştırmanın üretim kategorisine ilişkin oluşturulan metaforların gerekçeleriyle benzerlik göstermektedir. Alabaş, Kamer ve Polat'ın (2012) kariyer gelişimlerinde lisansüstü eğitim üzerine öğretmenlerin görüşlerini aldıkları araștırmada, öğretmenlerin "Eğitim sorunlarına çözüm üretme" nedeni ile lisansüstü eğitimi tercih ettiklerini ortaya koyması yine lisansüstü eğitim kavramının üretim kategorisi ile paralellik gösteren bir sonuçtur.

Genel olarak değerlendirildiğinde; araştırma kapsamındaki öğretmen adaylarının lisansüstü eğitime ilişkin algılarının olumlu düzeyde olduğu görülmektedir. Bu doğrultuda aşağıdaki öneriler geliştirilmiştir.

- Lisansüstü eğitim kavramına ilişkin öğretmen adaylarının görüşleri doğrultusunda ortaya konan gelişim, zirve, değer, uzmanlık, keşif-araştırma, yol gösterici, doyumsuzluk, üretim kategorileri dikkate alındığında; öğretmen adaylarının lisansüstü eğitime ilişkin algılarının pozitif yönde ve beklentilerinin yüksek düzeyde olduğu dikkat çekmektedir. Öğretmen adaylarının hem bu beklentilerinin karşılanabilmesi hem de mesleklerini yerine getirirken sağlayacağı katkı göz önünde bulundurularak öğretmen adayları lisansüstü eğitime yönlendirilmelidir.

- Öğretmen adaylarının görüşleri doğrultusunda ortaya konan çaba ve zor kategorileri dikkate alındığında; öğretmen adayları lisansüstü eğitimi hem zor ve meşakkatli hem de emek ve çaba gerektiren bir süreç olarak görmektedir. Bu sürece ilişkin öğretim elemanları tarafından öğretmen adaylarına lisansüstü eğitim konusunda üniversiteye başladıkları ilk yıldan itibaren, ihtiyaçları doğrultusunda düzenli danışmanlık hizmetleri verilmelidir. Böylece lisansüstü eğitimin zor ve emek gerektiren bir iş olmasının yanı sıra önemi öğretmen adaylarına aşılanarak akademik istekliliklerinin artması sağlanabilir.

- Akademik ortamları önceden tanıyabilmeleri, lisansüstü eğitim hakkında bilgi sahibi olabilmeleri için öğretmen adaylarının hem lisans hem de lisansüstü eğitimleri süresince sempozyum, kongre, panel gibi etkinliklere katılımı sağlanmalıdır.

- Öğretmen adayları ile birlikte koordineli bilimsel araştırmalar yürütülmeli ve bu süreçte aktif görev almaları sağlanmalıdır.

- Benzer çalışmalar farklı üniversitelerde ve daha geniş gruplarda yürütülerek araştırma sonuçlarının karşılaştırılması alana katkı sağlayacaktır.

Yukarıdaki öneriler doğrultusunda; öğretmen adaylarının lisansüstü eğitim programlarına katılmasına imkân verilerek hem güçlü ve nitelikli akademik ortamların oluşmasına hem de daha nitelikli öğretmenlerin yetiştirilmesine katkı sağlanacağı düşünülmektedir. 


\section{KAYNAKLAR}

Akyüz, Y. (2010). Türk eğitim tarihi. M.Ö 1000 - M.S. 2010. Ankara: Pegem Akademi.

Alabaş, R. (2011). Social studies teachers' conception of postgraduate education preferences and its contribution to their professions. Procedia-Social and Behavioral Sciences, 15, 2897-290.

Alabaș, R., Kamer, s. T. ve Polat, Ü. (2012).Öğretmenlerin kariyer gelişimlerinde lisansüstü eğitim: tercih sebepleri ve süreçte karşllaştıkları sorunlar. e-International Journal of Educational Research, 3 (4). 89-107.

Arıcı, H. (2001). Türkiye bilimler akademisi: Bilim adamı yetiștirme lisansüstü eğitim. Ankara: TÜBİTAK Matbaası.

Aslan, C. (2010). Türkçe eğitimi programlarında lisansüstü öğrenim gören öğrencilerin akademik özyeterliklerine ilişkin görüşleri. Mehmet Akif Ersoy Üniversitesi Eğitim Fakültesi Dergisi, 10 (19), 87-115.

Başer, N., Narlı, S. ve Günhan, B.(2005). Öğretmenlerin lisansüstü eğitim almalarında yaşanan sorunlar ve çözüm önerileri, DË̈ Buca Eğitim Fakültesi Dergisi (Özel Sayı 1), 17, 129-135.

Bülbül, T. (2003). Ankara Üniversitesi Eğitim Fakültesinde görev yapan öğretim üyelerinin lisansüstü öğretime öğrenci seçme sürecine ilişkin görüşleri. Ankara Üniversitesi Eğitim Fakültesi Dergisi, 36, $1-2$.

Cerit, Y. (2008). Öğretmen kavramı ile ilgili metaforlara ilişkin öğrenci, öğretmen ve yöneticilerin görüşleri. Türk Eğitim Bilimleri Dergisi, 6 (4), 693-712.

Çakar, Ö. (2001). Türkiye bilimler akademisi: Bilim adamı yetiştirme lisansüstü eğitim. Ankara: TÜBITAK Matbaasl.

Eraslan, L. (2011). Sosyolojik metaforlar. Akademik Bakış Dergisi, 27, 1-22.

Gömleksiz, M. N. ve Et. S. Z. (2013). Öğretmen adaylarının lisansüstü eğitime iliş̧kin metaforik alglları. VI. Ulusal Lisansüstü Eğitim Sempozyumu (10-11 Mayıs 2013), Sakarya Üniversitesi. VI. Ulusal Lisansüstü Ĕ̆itim Sempozyumu Bildiriler Kitabı, 145-151.

Gömleksiz, M. N. ve Yıldırım F. (2013). Lisansüstü eğitim alan öğrencilerin lisansüstü eğitime ilişkin görüssleri. VI. Ulusal Lisansüstü Eğitim Sempozyumu (10-11 Mayıs 2013), Sakarya Üniversitesi. VI. Ulusal Lisansüstü Eğitim Sempozyumu Bildiriler Kitabı, 68-74.

İyibil, Ü. G. ve Akpınar, M. (2013). Fen bilgisi öğretmen adaylarının lisansüstü eğitimle ilgili bilgileri, bilgi kaynakları ve eğilimleri. VI. Ulusal Lisansüstü Eğitim Sempozyumu (10-11 Mayıs 2013), Sakarya Üniversitesi. VI. Ulusal Lisansüstü Eğitim Sempozyumu Bildiriler Kitabı, 234-239.

Karakütük, K. (2001). Öğretim üyesi ve bilim insanı yetiștirme: Lisansüstü öğretimin planlanması. Ankara: Anı Yayıncillk.

Köksalan, B., İlter, İ. ve Görmez, E. (2010). Sınıf öğretmeni adaylarının sosyo-kültürel özellikleri ve lisansüstü eğitim isteklilikleri üzerine bir çalışma (Fırat, Erzincan ve İnönü üniversitesi sınıf öğretmenliği ABD örneği) Ahi Evran Üniversitesi Eğitim Fakültesi Dergisi 11 (3) 277-299.

Lakoff, G. \& Johnson, M. (2005). Metaforlar: hayat, anlam ve dil. (Çev. G. Y. Demir). İstanbul: Paradigma Yayıncillk.

Merriam, S.B. (2013). Qualitative research: Nitel araștırma (Çev. Ed.: Selahattin Turan). Ankara: Nobel Yayıncillk.

Miles, M. B. \& Huberman, A. M. (1994). Qualitative data analysis: An expanded sourcebook. (2nd Edition). California: SAGE Publications.

Milli Eğitim Bakanlığı (MEB). (1996). XV. Millî Eğitim Şûrası. Online: http://ttkb.meb.gov.tr/meb iys dosyalar/2014 10/02113559 15 sura.pdf adresinden 20 Ekim 2015 tarihinde indirilmiștir.

Milli Eğitim Bakanlığı (MEB) (2009). MEB 2010-2014 Stratejik Planı. Ankara: T.C. Millî Eğitim Bakanlığı Strateji Geliştirme Başkanlığı. Online: http://sgb.meb.gov.tr/Str yon planlama V2/MEBStratejikPlan.pdf adresinden 20 Ekim 2015 tarihinde indirilmiștir.

Milli Eğitim Bakanlığı (MEB). (2010). 18. Millî Eğitim Şûrası Kararları. Online: http://ttkb.meb.gov.tr/meb iys dosyalar/2014 10/02113646 18 sura.pdf adresinden 20 Ekim 2015 tarihinde indirilmiştir.

Patton, M. Q. (2002). Qualitative research ve evaluation methods. Thousand Oaks, CA: Sage

Saban, A. (2004). Giriş düzeyindeki sınıf öğretmeni adaylarının "öğretmen" kavramına ilişkin ileri sürdükleri metaforlar. Türk Eğitim Bilimleri Dergisi, 2 (2), 131-155.

Saban, A. (2008). Okula ilişkin metaforlar. Kuram ve Uygulamada Eğitim Yönetimi, 55, 459-496.

Şahin, Ç., Demir, M. K. ve Arcagök, S. (2015). Öğretmen adaylarının lisansüstü öğretime yönelik görüşleri. Eğitimde Kuram ve Uygulama, 11(1), 304-320. 
Şaşmaz Ören, F., Yılmaz, T. ve Güçlü, M. (2012).Öğretmen adaylarının lisansüstü eğitime yönelik görüşlerinin analizi. Eğitim ve Öğretim Araștırmaları Dergisi, 1 (2), 189-201.

Şişman, M. (2006). Eğitim bilimine giriş. Ankara: Pegem A Yayıncılık

Tamimi, Y. (2005). Örgüt kültürünün metaforlarla analizi. Yayımlanmamış yüksek lisans tezi, Osmangazi Üniversitesi, Eskișehir.

Tavukçu, E., Özkardaş, B., Erzurum, F., Çiftçi, M.Y., Şahin, E.M. ve Bilgin, N. (2013). Sınıf öğretmeni adaylarının lisansüstü eğitime ilişkin görüşleri.(Necmettin Erbakan Üniversitesi Örneği). XII. Ulusal Sinıf Öğretmenliği Eğitimi Sempozyumu, 23-25 Mayıs 2013, 547-551.

Ünal, C.., \& İlter, İ. (2010). Sınıf öğretmeni adaylarının lisansüstü eğitime olan tutumları (Fırat, Erzincan ve İnönü Üniversitesi Sınıf Öğretmenliği ABD örneği). Atatürk Üniversitesi Sosyal Bilimler Enstitüsü Dergisi, 14(2), 1-18.

Varıș, F. (1972). Türkiye'de lisansüstü eğitim. Ankara: Ankara Üniversitesi Eğitim Bilimleri Yayınları.

Yıldırım, A. ve Şimşek, H. (2006). Sosyal bilimlerde nitel araştırma yöntemleri. (6. baskı). Ankara: Seçkin Yayıncıllk.

Yükseköğretim Kurumu Lisansüstü Eğitim ve Öğretim Yönetmeliği. (2015). Lisansüstü Eğitim Ve Öğretim Yönetmeliği (Resmi Gazete Tarihi: 01.07.1996 Resmi Gazete Sayısı: 22683). Online: http://www.yok.gov.tr/web/guest/icerik/-

/journal_content/56_INSTANCE_rEHF8BIsfYRx/10279/17377, adresinden 20 Ekim 2015 tarihinde indirilmiştir. 